\title{
The research on the cultivation strategy and outlet of the ethnic characteristics of the music in the Normal University of Yunnan Province

\author{
Yu Chen
}

\author{
Music and Dance College of Qujing Normal University, Yunnan,China \\ yuer2001yuer@163.com \\ Music and Dance College of Qujing Normal University, Yu Chen
}

\begin{abstract}
This subject is the general program of the science research fund of the Education Department of Yunnan Province in 2013, and the exploration of the cultivation strategy and outlet of the music of the music in Yunnan province. The project number: 2013Y010. Research team adheres to the first-hand data collecting, sorting out, analyzing and studying, in-depth in normal colleges of Yunnan Province, to visit Yunnan music class non matter cultural heritage, and visited the related investigation and study of the employer, after two years of research and achieved fruitful research results, the article 12 .
\end{abstract}

Keywords: Yunnan province; division; music; national characteristics; cultivation strategy

\section{云南省高师音乐类民族特色培养策略与出路的探索结题报告}

\author{
陈 郁 \\ 曲靖师范学院音乐舞蹈学院, 曲靖, 云南, 中国 \\ yuer2001yuer@163.com \\ 通讯作者: 曲靖师范学院音乐舞蹈学院 陈郁
}

中文摘要. 本课题是 2013 年云南省教育 厅科学研究基金一般项目, 《云南省高师音乐 类民族特色培养策略与出路的探索》, 项目编 号：2013Y010。课题组坚持第一手资料的采 集整理和分析研究, 深入云南省高师院校, 拜望云南音乐类非物质文化遗产传承人，走 访相关用人单位进行资料调查研究, 经过两 年的调查研究, 取得了丰硕的研究成果, 完 成论文十二篇。

关键词: 云南省; 高师; 音乐类; 民族特色; 培养策略

\section{一、引言:}

本课题主要研究的是在教育部高师音乐 教学改革的大背景下, 立足于统一的改革思 路和发展趋势, 把握本课题的民族特色培养 的研究方向, 结合云南地区的多民族特色, 调查分析用人单位对于音乐类人才知识和技 能方面的需求，寻求具有地方民族特色的音 乐类教育人才的培养模式, 使之既具备高师 音乐类人才的统一知识技能素养, 又适应当 今地区社会的特殊需求, 提高人才质量的科 学培养策略, 探索出一条, 有效培养现阶段 云南地区需要的专业人才的方法和途径。保 护云南民族音乐中的瑰宝, 抢救保护并积极 
传承这些民族音乐文化中的非物质遗产, 焊 接一条连接民族音乐文化精髓与高师音乐专 业特色教育的桥梁, 把优秀的民族音乐文化 融入到教学当中去, 不仅对云南的这些优秀 的民族音乐文化是一种保护和传承, 也是丰 富学生民族知识素养, 提高就业竞争力的一 种方法和途径。身处云南高等音乐院校, 挖 掘保护和积极传承这些民族文化瑰宝, 是我 们高师人的责任。

\section{二、研究现状及趋势:}

近年来, 中小学教师岗位需求不断紧缩, 原本无人问津的 “特岗” 招聘, 现在也已然 成为了多手可热的 “香饽饽”, 师范类院校培 养的毕业生, 其主要就业方向也从教师岗位 转向了各行各业。在巨大的就业压力下, 许 多师范类高校的中小学音乐教师培养方案, 都在教育部教育改革的大背景下不断完善, 但成效并不显著。就师范类院校而言, 学校 的课程设置, 必定会在而后的工作岗位上得 到检验, 因此, 探索有别于单一 “生产线” 式的, 符合社会就业需求的多元性、民族性、 地区性的培养策略, 就显得弥足轻重了。

云南地处我国西南边陲, 拥有 56 个民族 当中的 52 个, 丰富多彩的民族音乐文化在这 片热土上不断繁衍生息。随着改革开放、经 济一体化与城镇化程度的推进, 千百年来原 生态的自然人文环境遭到了不同程度的破 坏, 相当部分的少数民族音乐文化已经到了 濒临绝迹的诺境, 发展经济与保护 “非遗” 貌似成为了一对不可调和的矛盾体。

\section{三、课题研究的实际意义}

作为传播音乐文化前沿阵地的高师音乐 院校, 怎样跟上国际教育发展的潮流、探索 出具有本地区民族特色的培养策略, 有效提 高区域音乐类师范生就业竞争力, 以及提供 传承民族音乐文化可持续性发展的人才储 备, 这些都是现今函待解决的社会问题。探 索培养出既具高校师范生基本音乐素质, 更 备优秀地方民族音乐文化特色核心竞争力的 优秀毕业生, 是本课题研究的实际意义之一。 民族音乐文化的学习与推广, 也是对非物质 文化遗产的一种有效的保护和传承, 避免云
南多姿多彩的民族艺术瑰宝不至于掩埋于现 代化的历史长河, 是本课题研究的又一实际 价值体现。

\section{四、研究现状理论综述:}

基于高师音乐类就业出路, 探索具备竞 争力的培养策略, 是一个亟待构建的理论框 架。但迄今为止, 教育惯性的影响与认识深 度的缺乏等种种原由, 令这方面的研究仅限 于零星论文的探讨。从中国期刊全文数据库 检索, 仅有以下几篇相关代表论文: 2006 年, 邵洁的国际会议论文《少数民族民间音乐在 民族地区音乐基础教育改革中的地位》主要 论述了民族民间音乐的重要性, 尤其指出少 数民族音乐文化亟待保护，从民族性的实质、 音乐教育自身原则与要求以及新大纲对地区 可补充 20\%的乡土音乐教材标示三个方面阐 述了音乐基础教育中开展民族民间音乐教育 的观点。2012 年, 冒小瑛在《黄河之声》刊 表的论文《浅谈我国少数民族音乐文化与高 校音乐教育改革的重大关系》提出了高校音 乐教育是少数民族音乐文化得以传承的重要 方式，也是国家文化教育实现历史性的前提。 并阐述了高校音乐教育要将少数民族音乐这 一文化形式在理论和形式上进行总结并传 达, 使其能够保持长久的生命力这一观点, 并强调了能否将二者恰当融合也是评价高校 音乐教育的改革是否合格的关键标准。2012 年，卢国文在《现代传播》中发表的论文《少 数民族音乐文化与高校音乐教育改革》阐述 了少数民族音乐教育不仅是国家文化教育中 的一种体现, 而且在很大程度上影响着民族 文化和教育的发展。高校音乐教育改革与少 数民族音乐的可持续性发展互为牵绊依靠。 因此, 得出高校音乐教育改革需要明确教改 的方向, 注重实效, 加强少数民族音乐教育 的学科建设的的观点。通过对以上文献资料 的分析, 我们发现有一些值得研究者去解决 的问题: 首先, 调查数据不明确, 缺乏说服 力的依据; 其次研究区域不均衡, 西南片区 对这方面的研究较少; 再次, 研究汉族的较 多, 以地区性少数民族特色为样本的实证研 究较少; 最后, 没有把系统的深层次的理论 与实际指导相结合的研究, 对地区实际指导 作用不大。因此, 本课题构建的具有现实指 
导意义、可供操作的教改框架也将具备深层 次的理论研究价值。

\section{五、课题研究的思路方法:}

云南省地处我国西南经济教育欠发达地 区，云南省经济文化发展缓慢、教育基础薄 弱、生源素质普遍偏低、省内高校全国排名 不尽如人意等因素, 最终都导致了云南省高 校毕业生整体竞争力不强, 就业率不高的现 状。课题组在教育部教学改革的大背景下, 明确高师音乐教育的改革思路和发展趋势, 准确把握课题整体思路, 在省教育厅《高师 音乐学 (教师教育) 本科声乐课程教学改革 研究》课题的研究基础上, 对云南高师地区 民族特色音乐教育进行调查研究, 力图在高 师音乐教育、民族文化传承、人力资源培养 三个方面找到切合点, 为课题研究提供有理 有据的理论依据。

本课题采用前期走访分析、实践调查与 后期文献梳理、理论研究相结合的研究方法。

前期调查研究包括对就业资料的搜集整 理与分类调查和对用人单位的招聘需求走访 调查。首先, 对现阶段云南高师音乐类培养 方案进行梳理分析研究，其次，对近三年云 南省音乐类师范生的就业情况进行统计研 究, 再次, 对不同类型用人单位进行走访调 查及结果分析, 调查在云南少数民族分布下 的，具有民族特色的音乐人才需求的情况。

基于实践调查的分析结果，在教育部高 师音乐类教学改革基础上, 结合教育学、心 理学等理论方法以及民俗学、民族学、音乐 学、美学等理论知识, 探寻研究出具有云南 地区民族特色, 特别是吸取优秀少数民族音 乐文化瑰宝的培养方式和策略, 最终形成具 有实践价值和理论意义的两篇论文。

\section{六、课题研究的主要内容:}

课题从三个方面进行研究，第一，结合 云南地区的多民族特色, 调查分析用人单位 对于音乐类人才民族特色知识和技能方面的 需求。第二，云南地区民族音乐的保护和发 扬方面，保护云南民族音乐中的瑰宝，不仅 可以挖掘保护和积极传承这些非物质文化遗 产，也是丰富学生民族知识素养，提高就业
竞争力的一种方法和途径。第三，要在教育 部高师音乐教学改革的大背景下，立足于统 一的改革思路和发展趋势，把握本课题的民 族特色研究方向, 探索出一条, 有效培养现 阶段云南地区需要的专业人才的方法和途 径。

\section{七、课题研究的结果:}

1. 针对课题要求的第一项研究目标, 完成 论文《云南师范院校音乐教育就业形式分析报 告》，文章就云南某师范院校音乐教育专业 11--13 年毕业生就业情况进行分析, 在了解 高师音乐类学生毕业后的就业情况后, 找出其 中的一些不足进行改革建议, 作为以后学校的 招生指南, 在招生人数、课程设置方面进行改 革的依据，以便今后更好地为社会培养人才。

2. 针对第二项研究目标, 课题组运用三篇 论文阐述了研究结果。论文《论高师音乐教学 与云南民族音乐资源的传承保护》，阐述了高 师音乐教学的目的是培养中小学生合格的音 乐教师，是民族音乐传承中承上启下的桥梁， 在高师音乐教育中增加民族音乐, 是传承民族 文化的重要手段, 是对云南民族音乐资源的一 种传承和保护; 论文《简析云南地区音乐类非 物质文化遗产对提升高师音乐教育就业的探 索》, 文章从生源选拔、课程开设、教材内容 和教学方式四个环节阐述云南地区音乐类非 物质文化遗产在高师音乐教育中的开发与利 用, 使之引入高师音乐教育具有非常大的可行 性和实用性。随着国家、社会对于非物质文化 遗产保护的重视, 非物质文化遗产传承的人才 需求缺口非常大。云南地区的高师音乐教育加 强对音乐类非物质文化遗产的开发和利用，对 于提高教学质量、改善学生就业难的问题具有比较 积极的意义；论文《云南地区音乐类非物质文化遗 产借助高师音乐教育专业课堂的传承与保护》. 与物 质文化遗产有所不同的是，非物质文化遗产是需要 以传承为基础和前提而存在的，因此将音乐类非物 质文化遗产引入到高师音教课堂教育中，不仅能够 更好的促进音乐类非物质文化遗产的传承与发展， 而且还能够促进高师音教课程体系的完善，从而使 非物质文化遗产的地位得以提高。文章从音乐类非 物质文化遗产进入高师音教课堂的作用和对策两个 方面进行阐述，从课程体系、师资队伍、教材内容 等方面进行一系列的加强和完善, 有助于更好的促 
进音乐类非物质文化遗产的传承与发展, 将高校和 民间两者之间的传承进行有效的结合。

3. 最后一项研究目标, 完成论文《高师 音乐人才民族特色培养》, 从高师音乐教育专 业现状和就业形式，以及构建多元化 “民族音 乐” 特色培养的意义, 探索出云南高师音乐教 育专业人才民族特色培养的一些启示; 论文

《云南高师音乐教育中文化遗产事业的人才 培养模式探究》, 就非物质文化遗产事业之音 乐类的人才培养模式的客观必要性进行了分 析, 从而探索音乐类非物质文化遗产事业的人 才培养模式; 论文《云南高师音乐教学中民族 特色培养的改革探索》首先分析了云南高师音 乐教学的现状, 然后从建设具有本土民族文化 特色的多元化教育理念，把 “弘扬民族音乐， 理解多元文化” 视为教育教学的基本理念, 重 视云南少数民族音乐文化与其他民族音乐文 化的相通、相容, 使其成为理解、包容具有地 方特色的教育文化, 是多元音乐教育理念宗旨 的重要意义所在, 最后从开拓本土音乐教材方 面, 创建具有民族特色的教育内容, 整理少数 民族音乐文化并整理成系列性的教科书, 应用 于教学中去; 论文《高师声乐教学中民族特色 培养的改革探索》首先论述了当前高师声乐教 学在民族特色培养方面存在的不足, 教学西化 严重, 内容存在缺失; 教学方法陈旧, 教学思 想落后, 然后从高师声乐教学中民族特色培养 的改革路径方面进行论述, 举出, 做好教学定 位, 改变教学思想; 合理教学安排, 凸显民族 特色; 创新教学手段, 激发民族感情等方法。还有 三篇论文分别从民族器乐集体课、钢琴课程、学生 创新能力培养方面阐述现状, 探索高师音乐课程改 革建议, 树立新的音乐教育专业人才培养观, 以学 生为本、加强培养实践能力, 重新对高师音乐教育 进行定位与精准分析, 正确结合高师教育的特点发 挥其作用并达到教学目标。探索一条符合自身特点 的人才培养道路, 研究新型人才培养模式, 充分发 挥高师音乐教育在地方音乐教育中的带头作用。

\section{八、论文成果目录:}

1. 陈郁. 云南省高师音乐类民族特色培养 策略与出路的探索结题报告

2. 陈郁. 高师音乐人才民族特色培养 $[\mathrm{J}]$. 《音乐时空》2014(08)

3. 陈郁. 论高师音乐教学与云南民族音乐
资源的传承保护 $[\mathrm{J}]$. 《戏剧之家》2014(08)

4. 陈郁. 云南师范院校音乐教育就业形式 分析报告 $[J]$. 《戏剧之家》2014(11)

5. 陈郁. 简析云南地区音乐类非物质文化 遗产对提升高师音乐教育就业的探索 $[\mathrm{J}]$. 《北 方音乐》2014(11)

6. 陈郁. 云南地区音乐类非物质文化遗产 借助高师音乐教育专业课堂的传承与保护 [J]. 《北方音乐》2014(12)

7. 陈郁. 云南高师音乐教育中文化遗 产事业的人才培养模式探究 [J].《音乐时 空》2015(03)

8. 赵肖, 刘学梁. 高师钢琴课教学现 状及其改革建议 $[J]$. 《北方音乐》 2014 (07)

9. 田向弘, 鲁庆华. 高师音乐学技能 课探讨之一一民族器乐集体课 $[\mathrm{J}]$. 《群文 天地》2013 (01)

10. 田向弘. 高师民族音乐教学中学生创 新能力培养的思考 [J]. 《南风》2014（09）

11. 陈郁. 云南高师音乐教学中民族特色 培养的改革探索 $[J]$. 《品牌》2015(06)

12. 陈郁. 高师声乐教学中民族特色培养 的改革探索 $[J]$. 《艺术品鉴》2015(07)

\section{九、课题研究的结论:}

研究成果的关键在于, 探索出一条具有 民族特色的高师音乐类培养方式，使民族特 色培养教育、地区非物质文化遗产的保护和 传承、人力资源培养目标之间循环发展, 串 联他们之间的真空地带, 保护地区优秀特色 民族文化的同时，缓解高师教育与社会就业 的矛盾冲突。

\section{十、研究结果的意义和价值:}

本课题调查研究的地区就业现状和需求 之间的差异, 对日愈严峻的高师音乐类毕业生 的就业发挥着有效的指导作用,最终形成的基 于社会就业需求的培养方式和策略成果, 将对 高师音乐类学生的培养提供科学的方向和方 法。

依托于高师音乐专业教育的地区民族文 化, 特别是云南少数民族音乐 “非物质文化遗 产”, 将得到最大程度的保护和传承, 为地区 
音乐文化的可持续性发展提供动力支持和后 台保障。

\section{十一、结束语:}

纵观本项目的研究内容、目标、方法和进 程, 使课题组更加清醒地认识到: 云南省高师 音乐类民族特色培养策略与出路的探索是一 个极其复杂的系统工程,完美的研究成果需要 各个方面的支持, 需要更加长期的合作努力, 需要更加持之以恒的研究过程。必须通过更深 入、更广泛、更密切、更长期的研究, 才有可 能从根本上解决以下问题:

一是要更加充分认识民族特色培养, 在学 生音乐专业素养中不可替代的独特作用。

二是提高高师音乐类学生的就业率, 不止 一条出路, 一个办法, 需要我们通过就业信息 的调查分析, 反映到教学当中去, 不断适应社 会的需求。

三是加强非物质文化遗产的保护, 不仅在 当下，亦在传承。

\section{致谢}

本文为云南省教育厅科学研究基金一般 项目《云南省高师音乐类民族特色培养策略与 出路的探索》 (项目编号：2013Y010) 的终结 性成果。

\section{References}

[1] Bo S.,Shiqi S.On the theoretical value and practical significance of the multicultural music in the higher teachers in Yunnan,Journal of Yunnan Arts University.April,2008.

[2] Ge W.Art education and art application ,Art Education. February,2009.

[3] Xifei X,fei X.Exploration on the cultivation mode of the compound applied music education personnel, People's Music,March,2008.

[4] Ge W. Thinking of the intangible cultural heritage into the college music teaching classroom of non music class, People's Music,February,2008. 